Review

\title{
Pathways for the effects of increased nitrogen deposition on fauna
}

\author{
M.E. Nijssen ${ }^{\mathrm{a}, \mathrm{b}, *}$, M.F. WallisDeVries ${ }^{\mathrm{c}, \mathrm{d}}$, H. Siepel ${ }^{\mathrm{b}, \mathrm{e}}$ \\ a Bargerveen Foundation, P.O. Box 9010, 6500 GL Nijmegen, The Netherlands \\ b Department of Animal Ecology and Physiology, IWWR, Radboud University Nijmegen, The Netherlands \\ c Laboratory of Entomology, Wageningen University, P.O. Box 16, 6700 AA Wageningen, The Netherlands \\ d De Vlinderstichting/Dutch Butterfly Conservation, P.O. Box 506, 6700 AA Wageningen, The Netherlands \\ e Plant Ecology and Nature Conservation Group, Wageningen University, P.O Box 47, 6700 AA Wageningen, The Netherlands
}

\section{A R T I C L E I N F O}

\section{Article history:}

Received 16 February 2016

Received in revised form 5 February 2017

Accepted 10 February 2017

Available online $\mathrm{xxxx}$

\section{Keywords:}

Acidification

Chemical stress

Eutrophication

Food web

Microclimate

Plant stoichiometry imbalance

\begin{abstract}
A B S T R A C T
Effects of increased $\mathrm{N}$ deposition, caused by agricultural practices and combustion of fossil fuels in traffic and industry, have been studied in detail for soil and water chemistry as well as for vegetation and ecosystem functioning. Knowledge on fauna is limited to descriptive and correlative data for a small number of species or communities. Therefore, mechanisms behind effects of $\mathrm{N}$ deposition on animal species and diversity remain unclear, which hampers optimisation of nature restoration and conservation measures.

The aim of this review is to identify and structure possible different pathways in which fauna is affected by high $\mathrm{N}$ deposition. We identify ten pathways leading to six basic potentially negative bottlenecks: (1) chemical stress, (2) a levelled and humid microclimate, (3) decrease in reproductive habitat, (4) changes in food plant quantity, (5) changes in nutritional quality of food plants and (6) changes in availability of prey or host species due to cumulative effects in the food web. Depending on species and habitat type, different pathways play a dominant role and interference between different pathways can strengthen or weaken the net effect of $\mathrm{N}$ deposition.

Although all identified pathways and bottlenecks are supported by peer reviewed literature, we conclude that scientific evidence on the causal relationship between increased $\mathrm{N}$ deposition and effects on fauna in the complete causal chain is still insufficient. We recommend that future research should aim to clarify the causal mechanisms underlying the observed changes in species composition attributed to $\mathrm{N}$ deposition. The most severe gaps in knowledge concern subtle changes in plant chemistry and changes in availability of prey and host species to higher trophic levels.
\end{abstract}

(c) 2017 Published by Elsevier Ltd.

\section{Introduction}

Excessive deposition of nitrogen $(\mathrm{N})$ caused by emission from combustion of fossil fuels in traffic and industry, and intensification of agriculture is a severe ecological problem at a global scale (Vitousek et al., 1997; Galloway et al., 2008; Sutton et al., 2014). Deposition levels of total $\mathrm{N}$ vary widely between regions worldwide, but exceed natural background deposition almost everywhere. These levels are not expected to decrease in the next decades and will probably further increase in regions with economic growth, especially Asia (Kanakidou et al., 2016). The pathways by which excess of nitrogen availability influences animal species and fauna diversity is an important, but poorly understood topic in ecosystem ecology. Scientific evidence is necessary to identify the risks to animal diversity in major ecosystems and to develop measures to counteract or mitigate negative effects.

\footnotetext{
* Corresponding author at: Bargerveen Foundation, P.O. Box 9010, 6500 GL Nijmegen, The Netherlands.

E-mail address: M.Nijssen@science.ru.nl (M.E. Nijssen).
}

Dominant mechanisms by which deposition of atmospheric nitrogen can affect natural ecosystems and forests were first reviewed by Skeffington and Wilson (1988). Ecological effects on soil and water chemistry, vegetation and ecosystem functioning have been described at a global scale (Vitousek et al., 1997; Sutton et al., 2014) as well as on the level of a single continent or nation (Liu et al., 2011; Stevens et al., 2011), gradients in climate, soil and vegetation types within regions (Simkin et al., 2016), aquatic and terrestrial ecosystem types (Geelen and Leuven, 1986; Remke et al., 2009; Ochoa-Hueso et al., 2011) and food webs (Throop and Lerdau, 2004; Meunier et al., 2016).

In general, increased $\mathrm{N}$ deposition leads to a higher availability of $\mathrm{N}$ for plants, increased acidification, mobilisation and leaching of cations, especially in habitats that are nutrient poor, $\mathrm{N}$-limited and have a weak acid buffering capacity (Simkin et al., 2016). These chemical changes result in an increased biomass production, asymmetric plant competition - most visible are algae in water, and tall grass and shrub species in terrestrial systems - and altered soil microbes (Farrer and Suding, 2016) leading to a decrease in variation of vegetation structure and plant species diversity (Bobbink et al., 2010; Cleland and Harpole, 2010; Sutton et al., 2014). Further field studies have expanded to 
cover changes in the abundance and activity of mycorrhizae (Mohan et al., 2014) and plant stoichiometry (Elser et al., 2010).

Animal communities are also affected by nitrogen-driven ecosystem changes and several studies describe changes in fauna groups in aquatic and terrestrial systems as a result of increased $\mathrm{N}$ deposition (e.g. Berg and Verhoef, 1998; Xu et al., 2009). These papers provide descriptive and correlative changes in patterns for fauna diversity, but lack causal explanations for these changes. Recently, several studies have been published which tested conceptual models on effects of $\mathrm{N}$ deposition in food webs, focusing on changes in plant-herbivore relations after releasing primary producers from $\mathrm{N}$-limitation and altering foliage $\mathrm{N}$ content, including consequences for predatory species (Meunier et al., 2016; Pöyry et al., 2016). Comparable to the review on chemical stress (Camargo and Alonso, 2006), they identify possible causal mechanisms by which fauna is affected. However, these studies also show a lack of experimental data and cover only a limited part of this ecologically complex subject.

Without a thorough overview and understanding of causal mechanisms behind effects of $\mathrm{N}$ deposition on animal species and fauna diversity, optimisation of conservation or restoration measures is impossible and can create unforeseen new bottlenecks (see for example the affected stoichiometry after sod-cutting in Vogels et al., 2016). The goal of this review is to identify and structure possible causal mechanisms leading to bottlenecks for animal species populations and fauna diversity following increased $\mathrm{N}$ deposition. This paper presents a conceptual model with ten different pathways by which high $\mathrm{N}$ deposition affects fauna, based on literature describing direct and indirect effects, thereby offering a logical framework for future research to adequately work on important deficiencies in knowledge on effects of excessive $\mathrm{N}$ deposition on fauna.

\section{Methods and constraints}

Literature was found by searching Web of Science (papers) and Google Scholar (books) on key words 'nitrogen deposition' + 'fauna*'|'animal"' and subsequent search in the citation history of all relevant sources. To further substantiate different pathways, a second literature search was performed with relevant effects on ecosystem level as key words: 'nitrogen deposition' + 'encroachment'/'vegetation composition'/'microclimate'/"nesting'/'flower"'/'food plant'/'stoichiometr*'/ 'prey'. The aim of this paper is to investigate causal effects of increased air-borne $\mathrm{N}$ deposition. Papers on fertilizer experiments (adding not only $\mathrm{N}$, but also other nutrients) and papers on effects of increased $\mathrm{N}$ availability due to local sources like polluted wastewater, sewage water or aquaculture were rejected, since eutrophication with multiple nutrients often only lead to increased plant biomass production, whereas airborne $\mathrm{N}$ deposition can lead to soil acidification and imbalanced stoichiometry as well. Papers describing changes in animal communities correlated with increased $\mathrm{N}$ deposition, but lacking causal mechanism, were only used as supportive literature for describing possible pathways.

The strict way of selecting only studies tackling causal mechanisms on effects of a measured amount of $\mathrm{N}$ deposition on fauna resulted in an insufficient number of studies for a data driven synthesis. We therefore chose a qualitative approach to arrive at a conceptual model of pathways for the effects of increased $\mathrm{N}$ deposition on fauna.

To link possible effects of increased N deposition on fauna with proven effects on ecosystem and vegetation level (Bobbink et al., 2010; Sutton et al., 2014), literature was first assigned to the following processes: changes in water and soil quality, increased growth of plant biomass, changes in vegetation structure and composition, and changes in plant stoichiometry. To understand the mechanistic link for fauna as well as to further select papers, which tackle more than one process on ecosystem level, literature was subsequently classified based on fundamental animal requirements: food, suitable abiotic conditions and (access to) reproductive habitat. In case of abiotic conditions, a split was made between direct chemical changes in habitat (in aquatic systems and moist soils) and indirect changes caused by increased growth of plant biomass. In case of food and reproductive habitat, all effects on fauna are indirect via changes in vegetation and changes within or between fauna groups on different trophic levels.

Effects on ecosystem level were placed in a flow scheme, starting with airborne ' $\mathrm{N}$ deposition' leading to changes in soil, water and plants (Fig. 1; upper levels). Subsequently, all effects on fauna found in the literature were placed in this scheme and linked with relevant changes at the ecosystem level. Links between the different levels were (re)placed until all effects and pathways described in the literature fitted in the flow scheme (Fig. 1: lower level). This resulted in 10 different pathways (pathway a to $j$ ) leading to 6 basic bottlenecks for animal species. An overview of all literature used to identify these pathways and bottlenecks is given in Table S1 (supplement 1 ).

This study holds several constraints to ensure a compact overview, focussing on the causal pathways for effects of $\mathrm{N}$ deposition on fauna. 1) We cite relevant literature to clarify and substantiate all different pathways and bottlenecks, but do not go into detail on every effect nor give nuances for different ecosystems; where applicable we refer to other review papers. 2) We treat all effects on animal species or communities as basically negative, since human-induced $\mathrm{N}$ deposition above natural background levels alters the conditions and succession trajectories of pristine ecosystems, which is regarded as undesirable from a conservation point of view. Positive effects for single species or groups are sometimes mentioned as an example, but this mainly concerns facilitation of potentially dominant species that replace a greater number of vulnerable species. 3) Feedback mechanisms and interference with other global environmental changes, such as increasing temperatures and $\mathrm{CO}_{2}$ levels are briefly described in Section 4, but are not included in the conceptual model to keep it synoptic.

\section{Pathways for effects of $\mathbf{N}$ deposition on fauna}

Since the majority of effects of $\mathrm{N}$ deposition on fauna is indirect, it is necessary to link changes in soil and water quality and vegetation to the requirements of animal species to understand the most probable pathways affecting them (summarised in Fig. 1). These demands include food, suitable abiotic conditions and (access to) reproductive habitat (cf. Dennis et al., 2003).

Based on the available literature (see supplement 1), we derived the following possible bottlenecks for fauna as resulting from $\mathrm{N}$ deposition: 1) chemical stress, 2) a buffered microclimate (levelled temperatures and more humid) due to increased vegetation density, 3) decrease in reproductive possibilities for ground or soil living species, due to denser and taller vegetation, 4) changes in diversity and abundance of food plants, 5) changes in host plant quality, and 6) changes in prey and host species availability at higher trophic levels. We will present all six bottlenecks in more detail.

\subsection{Chemical stress}

Chemical stress for fauna due to increased $\mathrm{N}$ deposition occurs in aquatic environments and probably in wet soils (but evidence is lacking), where animals live in direct contact with ambient surface water or pore water. Effects of increased nitrogen emissions on aquatic fauna were reviewed extensively by Camargo and Alonso (2006) for a wide variety of taxa, including molluscs, planarians, amphipods, decapods, insects and fish. Deposition-derived non-organic $\mathrm{N}$-compounds $\left(\mathrm{NH}_{4}^{+}\right.$, $\mathrm{NH}_{3}, \mathrm{NO}_{2}^{-}, \mathrm{HNO}_{2}, \mathrm{NO}_{3}^{-}$) can have direct toxic effects on aquatic fauna (Fig. 1; pathway a) and have been examined by laboratory studies. The physiological effects can be lethal in case of high toxic concentrations of $\mathrm{N}$ compounds, but mostly result in reduced feeding activity, fecundity and eventually survival, which decreases population sizes of aquatic animals (Camargo and Alonso, 2006). 


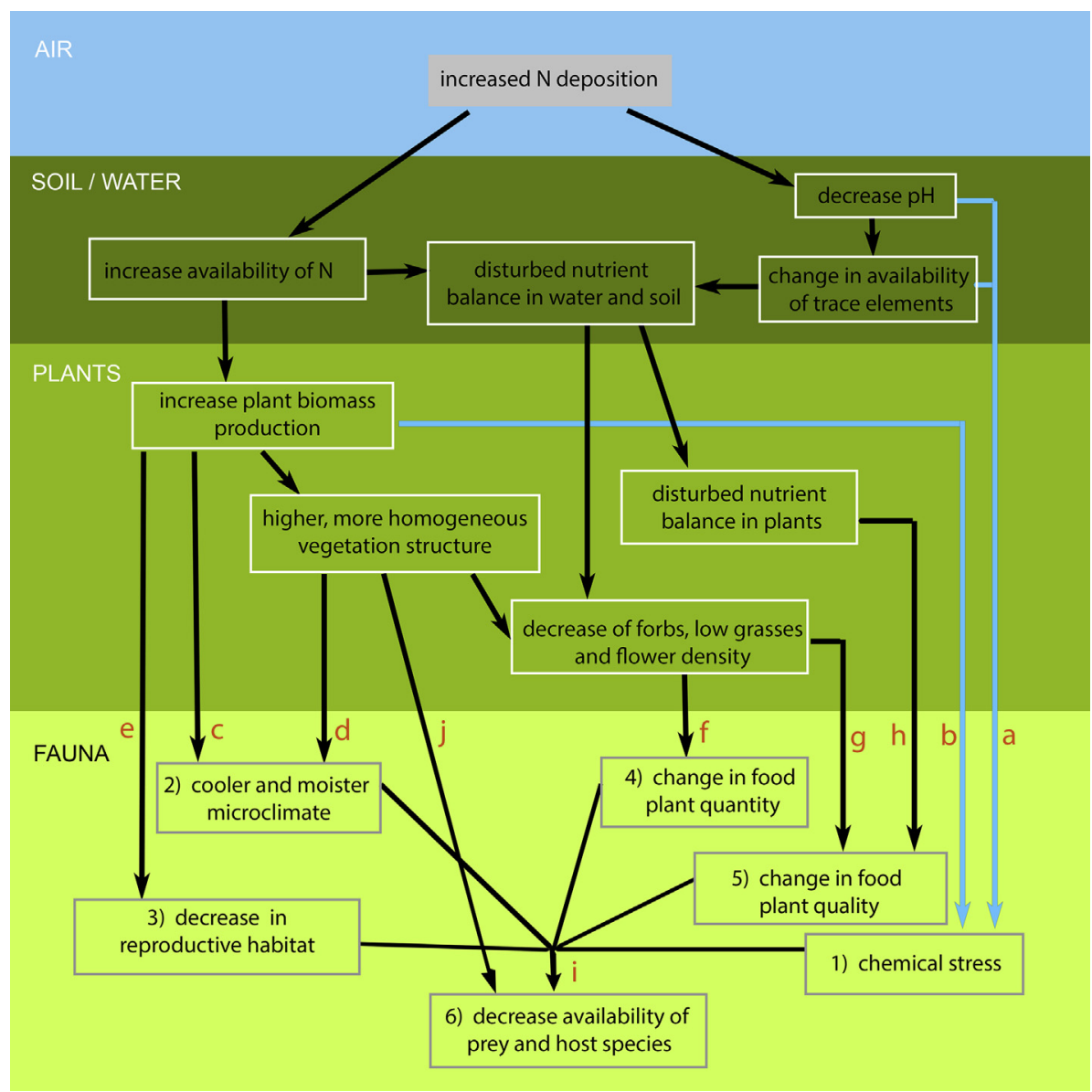

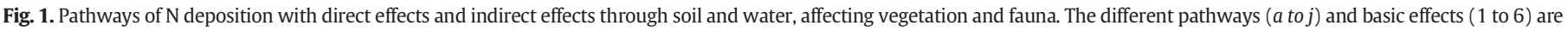

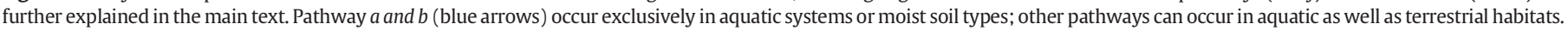

Enrichment of water with ammonium $\left(\mathrm{NH}_{4}^{+}\right)$increased mortality of young larvae of frog species Rana temporaria, with more pronounced effects at low $\mathrm{pH}$, but did not result in higher mortality rates for eggs of the frog species (Leuven et al., 1986a). Unionised ammonia $\left(\mathrm{NH}_{3}\right)$ is toxic to various aquatic animals, especially to fish (salmonids), where it can lead to damage to the gill epithelium, reduction in blood oxygen-carrying capacity, inhibition of ATP production and depletion of ATP, disruption of blood vessels and osmoregulation upsetting liver and kidneys and repression of the immune system (Camargo and Alonso, 2006). Both nitrite $\left(\mathrm{NO}_{2}^{-}\right)$and unionised nitrous acid $\left(\mathrm{HNO}_{2}\right)$ are toxic (Camargo et al., 2006), mainly to fish and crayfish, due to conversion of oxygen-carrying pigments causing hypoxia, disruption of $\mathrm{Cl}^{-}$and $\mathrm{K}^{+}$levels causing severe problems with membrane potentials, neurotransmission, skeletal muscle contractions and heart function, formation of mutagenic and carcinogenic $\mathrm{N}$-nitroso compounds, damage to mitochondria in liver cells and repression of the immune system. Intake of nitrate $\left(\mathrm{NO}_{3}^{-}\right)$in aquatic animals is much lower than $\mathrm{NO}_{2}^{-}$uptake due to low branchial permeability, which makes this compound less toxic. However, nitrate can be converted to nitrite under internal body conditions and subsequently inhibit oxygen transport. Early developmental stages of some marine invertebrates, caddisflies, amphipods and fish seem to be the most sensitive groups. Sensitivity of amphibians to nitrate may also be high and seems connected with decreased body size, fecundity and survival and impaired swimming ability (Camargo and Alonso, 2006). Toxic effects of inorganic nitrogenous compounds are less pronounced in marine environments, because of the inhibiting effect of water salinity (sodium, chloride, calcium and other ions) as well as a higher tolerance of marine species. Although effects on animal species in wet soils are expected to be similar to those in aquatic systems, evidence is lacking and it is uncertain to which degree these occur. Other direct toxic effects result from acidification (pathway $a$ ) and the subsequent increases in concentration of $\mathrm{H}^{+}$and - in some cases - an increase in dissolved $\mathrm{Al}^{3+}$ and other trace metals $(\mathrm{Cd}, \mathrm{Cu}, \mathrm{Pb}, \mathrm{Zn})$ above critical levels. These effects are observed during extreme atmospheric deposition of $\mathrm{HNO}_{3}, \mathrm{NH}_{4}^{+}$and $\mathrm{H}_{2} \mathrm{SO}_{4}$ ('acid rain') (Camargo and Alonso, 2006).

Acidification can lead to disruption in ionic regulation, respiration and metabolism in molluscs, insects, crustaceans, fish and amphibians. Furthermore, acidification can cause mortality or hatching delay in eggs of fish and amphibians, arrested development in fish and amphibian embryo's, reduced moulting success in insects and crustaceans and reduction of feeding activity or efficiency and growth rates in many invertebrate and vertebrate fauna groups. Severe acidification diminishes populations of fish and aquatic snails are absent at $\mathrm{pH}<5.0$ (Leuven et al., 1986b; Leuven and Oyen, 1987; Økland, 1992). Strong acidification $(\mathrm{pH}<3.5)$ of reproductivepools and lakes for amphibians leads to egg mortality, but at $\mathrm{pH}<5$ hatching rate of eggs already decreases due to fungal infections (Saprolegniaceae) (Leuven et al., 1986a). When ranking different stressors linked with $\mathrm{N}$ deposition, $\mathrm{pH}$ proves to be the largest threat for amphibians, followed by copper and ammonium, while nitrate and cadmium were of minor importance (Fedorenkova et al., 2012). In aquatic invertebrates uptake of metals by surface absorption as well as toxicity of ingested metals $(\mathrm{Cu}, \mathrm{Pb}, \mathrm{Cd}, \mathrm{Zn})$ increase with decreasing $\mathrm{pH}$ of the water, but the net effect varies as a function of feeding habits, body size and lifespan of species (Gerhardt, 1993). Compared with direct pollution of heavy metals the increase of metal concentrations due to $\mathrm{N}$ deposition is relatively low and can change their behaviour and thereby decrease survival and reproduction or 
increase predation risk (Mogren and Trumble, 2010), rather than lead to direct mortality. All aquatic invertebrates (Rainbow, 2002) and vertebrates (e.g. Sauliutè and Svecevičius, 2015) take up and accumulate metals in trophic food chains, but the effects of nitrogen-induced increase of metals on higher trophic levels is probably low.

Other effects of increased $\mathrm{N}$ deposition in aquatic systems are due to the enhanced development, maintenance and proliferation of primary producers (Fig. 1; pathway b). Unlike chemical intoxication, the increase in biomass growth of phytoplankton, macroalgae and macrophytes is a visible effect associated with eutrophication of water bodies. However, when inorganic nitrogen stimulates growth of toxic algae, cyanobacteria, dinoflagellates and diatoms, fauna can be exposed to high levels of extracellular organic toxins in ambient water and ingestion of intracellular organic toxins. These might not be lethal for primary consumers, but since algal toxins can be bio-accumulated and transferred through food webs, aquatic as well as terrestrial carnivorous species may be indirectly exposed when consuming aquatic fauna containing toxins (Camargo and Alonso, 2006). Increased plant biomass and the subsequent decomposition of organic matter usually lead to low dissolved oxygen levels in water and sediments, especially when water turnover rates are low. Invertebrates as well as fish can die from hypoxia or anoxia or experience toxic stress when reduced oxygen concentrations lead to formation of reduced compounds like hydrogen sulphide $\left(\mathrm{H}_{2} \mathrm{~S}\right)$ (Camargo and Alonso, 2006).

\subsection{Buffered microclimate: levelled temperature and higher humidity}

Research on the causal relationships between $\mathrm{N}$ deposition, vegetation structure, microclimate and its effects on fauna is lacking. Therefore, the following description has been derived from handbooks on (the relation between) microclimate and fauna (Willmer, 1982; Stoutjesdijk and Barkman, 2014) as well as correlative studies on butterflies, grasshoppers, ants and birds (Schirmel et al., 2011; Van Noordwijk et al., 2012; Schekkerman and Boele, 2009; Schirmel and Fartmann, 2014).

Increased plant biomass production due to $\mathrm{N}$ deposition results in a higher and denser cover of vegetation and litter, which decreases irradiation of sunlight as well as air circulation close to the ground (Fig. 1: pathway $c$ ). In summer, the temperature sums in the soil and litter layer are lower in this dense vegetation compared to vegetation with an open structure without litter accumulation. At the same time soil moisture and air humidity increases due to the lack of air circulation, which in turn buffers temperature changes. This hampers soil warming in spring. Contrarily, it may result in relatively high temperatures and high air humidity in winter. These changes in temperature, humidity, solar radiation and wind can influence development, fecundity as well as survival of animals. Small ectotherms such as invertebrates are more vulnerable to changes in microclimate because of their dependence on external heat (especially radiation) for thermoregulation, their small size and larger surface to volume ratio than larger endothermic mammals and birds, although this is partly compensated by their ability to exploit more finely graded habitats (Willmer, 1982). However, this is hardly possible in a dense homogeneous vegetation structure (Fig. 1: pathway d).

Many ectothermic organisms require body temperatures of 30$35{ }^{\circ} \mathrm{C}$ for optimal growth and development, hence in temperate zones a warm microclimate is essential for these organisms (Shreeve, 1990; Stoutjesdijk and Barkman, 2014) even more pronounced at the limits of their distribution range (Roy and Thomas, 2003). A decreased temperature sum causes retarded development for eggs and immature stadia in invertebrates, with subsequent negative consequences for fecundity and survival. The total time needed for egg development is strongly temperature dependent and may be critically extended by grass encroachment. This has been demonstrated for grasshoppers by Van Wingerden et al. $(1991,1992)$ and is one of the most determining factors of differences in distribution and diversity of grasshopper species in dune and steppe grasslands, respectively (Schirmel et al., 2011; Fartmann et al., 2012). Klop et al. (2015) concluded that for Wall Brown butterfly (Lasiommata megera) microclimatic cooling through excess nitrogen contributed more to its dramatic decline than loss of host plants or changes in food plant quality. In Dutch calcareous grasslands fast growth of vegetation hampers characteristic ant species which are in need of higher temperatures in summer due to a short nest development time between colonisation and mating flights (Van Noordwijk et al., 2012). It has been argued that spring-developing, thermophile organisms, such as butterflies hibernating as egg or larva, are particularly sensitive to the cooling of microclimate due to increased shading and moisture levels at raised levels of biomass accumulation due to $\mathrm{N}$ deposition. This hypothesis is supported by a comparatively greater decline in egg-larva than in pupa-adult hibernating species in European countries with oceanic climates and high levels of $\mathrm{N}$ deposition (Wallis de Vries and Van Swaay, 2006). However, alternative explanations might be that a levelled temperature and less air circulation in winter causes increased mortality in hibernating eggs and caterpillars due to 1 ) increased fungal or parasitic infections, or 2) exhaustion of fat supplies in species of those that do not go into quiescence (non-diapause dormancy). In this last case, fat reserves can become exhausted at temperatures above the threshold for metabolic activity, but below that for active foraging. Evidence for either hypothesis is lacking.

Although ectothermic species are more vulnerable from changes in microclimate, also endothermic species like self-feeding chicks of the Black-tailed Godwit (Limosa limosa) appear to be sensitive to low temperatures and wet conditions in combination with low prey availability. Brooding of chicks by adults increased with rain and with worsening of chick condition, leaving less foraging time and thus potentially leading to a negative condition spiral under adverse conditions (Schekkerman and Boele, 2009). Because $\mathrm{N}$ deposition may lead to a higher and denser vegetation structure in grasslands, and resulting in a cool and moist microclimate as well as a decrease in prey availability (see pathway $i$ and pathway $j$ ). A negative effect on self-feeding precocial birds is possible, but to which degree and for which bird species is not yet known.

\subsection{Decrease in reproductive habitat for ground-dwelling species}

Increased production of vegetation and litter lead to a reduction of bare and scarcely vegetated soil in terrestrial as well as aquatic systems, which functions as reproductive habitat for many animal species (Fig. 1: pathway e). Both aboveground nesting localities, courtship and mating sites as well as underground oviposition sites decrease with encroachment. This is probably the most clearly visible and widely accepted pathway for effects of $\mathrm{N}$ deposition on fauna. However, neither causal studies regarding the whole sequence nor time series with combined monitoring of nitrogen deposition, changes in vegetation structure and fauna are available. Support for this mechanism is therefore based on studies on vegetation structure (reviewed in Bobbink et al., 2010 and Sutton et al., 2014) in combination with correlative and descriptive literature on the occurrence of animal species and biomass and litter accumulation in the field (without explicit link to $\mathrm{N}$ deposition), such as in ants and wasps (Peeters et al., 2004), butterflies (Bink, 1992; Streitberger et al., 2014), grasshoppers (Lensink, 1963; Schirmel et al., 2011; Wünsch et al., 2012) and breeding birds (Van Turnhout et al., 2012).

The general mechanism determining this pathway is the increase of physical resistance of the vegetation and top soil layer due to a higher and denser vegetation cover and accumulation of litter, making it impossible to deposit eggs on or in the ground or to exhibit courting or mating activity. However, since the reduction of reproductive habitat by increase of physical resistance of the vegetation is inseparable with changes in microclimate (Fig. 1: pathway c and pathway d) as well as decreased availability of prey (Fig. 1: pathway j), it is not possible to estimate the roles for these individual pathways from available evidence. 


\subsection{Changes in diversity and abundance of host plants}

Many animal species feed on specific plant species or species groups, either on fresh biomass, nectar and pollen or seeds, litter and humus. Changes in vegetation composition due to changes in soil or water quality caused by $\mathrm{N}$ deposition (Fig. 1: pathway f) may have severe consequences for fauna when hostplant species decrease in abundance or disappear, which is repeatedly observed in vegetation shifts from herbs and narrow-leaved grasses to broad-leaved grasses and shrubs (Bobbink, 1991; Stevens et al., 2004; Clark and Tilman, 2008; Sutton et al., 2014). Due to their reliance on single plants species, monophagous (or monolectic) animal species are in general more vulnerable to these changes than oligophagous (or oligolectic) species or nonspecialised polyphagous (or polylectic) species. Changes in the availability of host plants may occur in different ways: 1 ) host plants decline so much that densities are insufficient to support a viable population of the dependent herbivore (WallisDeVries, 2004), 2) host plants have changed their phenology and a mismatch in time develops with the phenology of animal species (Visser, 2008), and 3) the physical distance between host plants and other essential resources in the landscape (mating sites, nectar sources other than the host plant) becomes too large (Dennis et al., 2003).

Like a decrease in reproductive habitat (effect 3 ) the decrease of resource abundance due to $\mathrm{N}$ deposition is very likely, but again causal evidence on the relationship between $\mathrm{N}$ deposition and the decrease of plant-dependent animal species hardly occurs. Öckinger et al. (2006) found a correlation between the decrease of butterfly species and increased $\mathrm{N}$ deposition and suggest a decrease in abundance or availability of host plants. WallisDeVries et al. (2012) presented clear correlations between large-scale declines in flower-visiting insects and in flower abundancy, due to changes in vegetation composition, with $\mathrm{N}$ deposition as the most probable determining factor in nutrient-poor environments. The few examples of species-specific evidence of reduced host plant abundance or availability becoming a bottleneck is from the Marsh fritillary (Euphydryas aurinia) regarding the abundance and availability of the host plant Succisa pratensis in Wales (Fowles and Smith, 2006) and Czech Republic (Konvicka et al., 2003), availability of Viola canina for Niobe fritillary (Argynnis niobe) in Germany (Salz and Fartmann, 2009) and host plant species for the monophagous Bay Checkerspot Butterfly (Euphydryas edita bayensis) in North-America (Weiss, 1999).

Specialised mono- or oligolectic bee species are probably highly vulnerable from a decline in plant diversity (Biesmeijer et al., 2006; Fründ et al., 2010). However, bee species that build large colonies every year, like bumblebees, depend on a continuous and abundant supply of flowering plants throughout the season and will be threatened when flower density and diversity drops on a larger spatial scale. Although bumblebees have a wide range of plant species at their disposal (Goulson et al., 2002) species differ in the length of their tongues and body sizes, resulting in resource partitioning (Sowig, 1989; Westphal et al., 2006; Kleijn and Raemakers, 2008) and will, therefore, not be equally harmed by changes in plant composition. Recently, Scheper et al. (2014) were able to demonstrate the link between reduction of nectar plant diversity and bee diversity by identifying pollen loads from museum specimens.

\subsection{Changes in host plant quality for herbivores}

$\mathrm{N}$ deposition can change food plant quality for herbivores along two different pathways. With changes in plant species composition (Fig. 1: pathway $g$ ) the stoichiometry of the food resources for herbivores changes, which forces them to shift from optimal to suboptimal food plants (Elser et al., 2010). In plants uptake of nutrients can shift as a result of changes in soil and water quality by an increased availability of nitrogen as well as mobilisation and leaching of trace elements. This leads to changes in plant total nutrient concentrations as well as changes in nutrient ratios (Fig. 1; pathway $h$ ), which may have important consequences for the food quality of herbivores (Roem and Berendse, 2000; Elser et al., 2010). It is clear that the influence of changes in nutrient total concentrations and stoichiometry on fauna depends on both plant species and herbivore species (Throop and Lerdau, 2004), as well as their interaction (Throop, 2005). This variation is mostly associated with differences between trophic groups feeding on different plant parts (roots, leaves, and phloem) and with differences in chemical and physical defence between plants species (Persson et al., 2010). Despite this broad variation, three main effects can be distilled: 1) positive effects on herbivores due to enhanced N-concentrations in digestible form (affecting the competition between herbivore species), 2) negative effects due to enhanced N-concentrations in non-digestible or toxic compounds, and 3) negative effects due to detrimental changes in stoichiometry, mostly regarding P and trace metals.

A generally strong positive impact of $\mathrm{N}$ deposition on individual performance of herbivorous insects in response to increased total foliar $\mathrm{N}$ was deduced from a review by Throop and Lerdau (2004), with a suggestion of more pronounced effects on conifers than deciduous trees due to the stronger increase of foliar $\mathrm{N}$ responses in conifers. Jones et al. $(2008,2011)$ registered higher abundance of insect herbivores on oaks and bracken fern under high N-deposition levels. However, there seems to be a herbivore-dependent optimum concentration of foliar $\mathrm{N}$ with respect to insect survivorship, development, growth and reproduction, with falling rates when optimum levels are exceeded, which may lead to the second effect, enhanced non-digestible or toxic compounds. Fisher and Fiedler (2000) observed high pupal and larval mortality as well as a reduction in adult size for Copper butterfly (Lycaena tityrus) when foraging on plants reared under artificially increased $\mathrm{N}$ availability.

One causal factor determining optimum $\mathrm{N}$ levels is the increase of toxic foliar nitrate accumulation or N-based secondary metabolites, as has been shown for the leaf beetle Ophraella communa by Throop (2005). Larvae of the Monarch butterfly Danaus plexippus showed decreased growth rates when feeding on milkweed Asclepias urassavica with nitrogen addition. Foliar $\mathrm{N}$ concentration in this host plant was not correlated with cardenolide concentration, but toxicity per unit leaf weight of cardenolide was higher as $\mathrm{N}$ increased in excess of demand (Tao et al., 2014). Nijssen and Siepel (2010) showed that in Grey-hair grass (Corynephorus canescens) excess $\mathrm{N}$ is stored in an unidentified non-protein nitrogen (NPN), which may act as a feeding inhibitor. Marbled grasshoppers Myrmeleotettix maculata reared on N-enriched $C$. canescens showed higher mortality and decreased growth rates compared to individuals reared on non-enriched grass. Measurements of individuals caught in the field showed smaller individuals on locations with high $\mathrm{N}$ deposition $\left(35 \mathrm{~kg} \mathrm{~N} \cdot \mathrm{ha}^{-1} \cdot \mathrm{yr}^{-1}\right)$ compared with individuals in relatively low deposition locations (5-12 $\left.\mathrm{kg} \mathrm{N} \cdot \mathrm{ha}^{-1} \cdot \mathrm{yr}^{-1}\right)$.

Studies focussing on the effects of changes in plant stoichiometry on fauna in relation to $\mathrm{N}$ deposition are rare. The most frequently reported effect is an ecosystem shift from $\mathrm{N}$-limitation to P-limitation, especially in P-limited systems or in situations where much organic matter has been removed by mowing and sod-cutting (Güsewell, 2004; Vogels et al., 2016). This does not lead to problems for herbivores per se (Tao and Hunter, 2012), but effects may vary between closely related species. Experimentally increased N:P ratios in Nettle (Urtica dioica) led to a shorter development time and heavier caterpillars for Small tortoiseshell (Aglais urticae), but to lighter larvae (without difference in developing time) for European Peacock (Aglais io) (Audusseau et al., 2015). Changes in plant stoichiometry can be a result of changes in density or composition of soil arbuscular mycorrhiza that are vulnerable for eutrophication and acidification. Causal studies on this chain of cause-effect relationship are lacking, but Goverde et al. (2000) showed a 1.6 to 3.8 time lower survival and inhibited growth rates for the Common Blue butterfly (Polyommatus Icarus) when feeding on host plants grown 
without arbuscular mycorrhiza, an effect associated with a higher C:N ratio and higher leaf $\mathrm{P}$ content.

Whether deficiencies for herbivores lead to cumulative effects on organisms higher in the food chain is still an open question. Compared with plants (autotrophs), animals (heterothrophs) have high levels of stoichiometric homeostasis. Although a mismatch with changing plant quality may be expected, herbivores can cope with altered plant quality by changing foraging behaviour and/or post-ingestion assimilation and subsequent accumulation or excretion of surplus elements (Persson et al., 2010, Sardans et al., 2012), but both processes can be time and energy consuming and might lead to lower survival, fitness and fecundity of herbivores. Nevertheless, Audusseau et al. (2015) as well as Abbas et al. (2014) found increased C: $\mathrm{N}$ ratios in male bees and female grasshoppers that were positively correlated with changes in plant stoichiometry. Mulder (2010) shows an allometric correlation in the food web, where larger animals are less abundant in P-limited systems, possibly implying a cascade effect in the food chain. In case of calcium availability in relation to acidification it seems effects are liable to be greater if they involve losses of calcium-rich prey rather than change in prey chemistry (Ormerod and Rundle, 1998). Haddad et al. (2000) reported that nitrogen addition (with addition of other nutrients and trace metals) resulted in decreased overall insect species richness, but with a different response between trophic levels. Detritivores increased both in species richness and abundance, herbivores increased in abundance but decreased in species richness and parasitoids declined in abundance but species richness remained stable. At this moment, there is no evidence that toxic compounds or shortage of trace metals induced by excess nitrogen accumulate in the food web with cascading effects on higher trophic levels.

\subsection{Changes in prey and host availability for predators and parasitoids}

Predators and parasitoids depend for their food on the presence of sufficient prey items or hosts. When the latter experience negative effects of N-deposition in terms of population size, the species higher in the food chain will suffer as well, or even more (Fig. 1; pathway $i$ ). The following processes may be distinguished: 1 ) severe (local) reduction in numbers or even total disappearance of prey and hosts species, leading to direct food shortage or an increase in physical distance between foraging site(s) and other essential elements in the landscape (nesting, shelter, hibernation),2) reduction of the accessibility of prey or host due to locomotive obstruction or decreased sighting capacity in higher or denser vegetation, and 3) reduction in specific prey taxa leading to nutrient deficiency (mainly calcium). Although it is widely accepted that total abundance, diversity and visibility of prey and host species can decrease due to $\mathrm{N}$ deposition via pathways a to $j$ (Fig. 1), the cumulative effect and its consequences for carnivores and parasites in higher trophic levels are hardly ever measured (but see experiments of Haddad et al. (2000), mentioned in Section 3.5, and De Sassi and Tylianakis (2012)).

In aquatic environments, strong reduction and total vanishing of populations of fish and calcium-rich invertebrates are observed in relation to acidification. This is in line with strong decreases in calcium-rich invertebrates in forests, such as snails (Pabian and Brittingham, 2007). $\mathrm{N}$ deposition in the form of ammonium also contributes to acidification in soil and water, and probably still hampers the restoration of soil and water chemistry now that $\mathrm{H}_{2} \mathrm{SO}_{4}$ emissions from industry have been strongly reduced (Sutton et al., 2014).

Effects of acidification by airborne $\mathrm{SO}_{2}$ and $\mathrm{N}_{\mathrm{x}}$ deposition on higher trophic levels have been studied in birds, where calcium shortage in forests has led to weak egg-shells in the Great tit (Parus major) (Graveland et al., 1994), due to the reduction or disappearance of calcium-rich prey such as snails, isopods and diplopods. Pabian and Brittingham (2007) and Pabian et al. (2012) found lower bird abundancy in acidified dry forest, but experimental liming increased soil calcium and $\mathrm{pH}$ and led to increased snail and bird abundances. After liming, bird abundance was positively related to snail abundance. Decrease in reproductive success in Dippers (Cinclus cinclus) has also been linked to shortage of calcium-rich prey in streams (Ormerod et al., 1991; Tyler and Ormerod, 1992) although it could not be determined whether calcium deficiency affected birds with high fitness, or that birds with lower fitness were displaced to unfavourable (acidified) territories. Birds that have fish as an alternative prey (next to insects) can also suffer from calcium shortage when fish is not available, as was shown for chicks of Black tern (Chlidonias niger) that suffered from inadequate bone development in an acidic, degenerated raised bog (Beintema et al., 1997). In nutrient-poor forests, a shortage of minerals compared to nitrogen in the leaves of Oak (Quercus sp.) led to a reduction of amino acid synthesis in plants and hence protein source for caterpillars. Caterpillars of moth species greatly declined and in the chain caterpillar, Great tit (Parus major), Sparrowhawk (Accipiter nisus) the latter bird species also suffered most from amino acid deficiencies. A strong reduction of flight muscles was seen during the breeding season, lower amount amino acids in eggs and abnormalities in egg-development related to this deficiency (Siepel et al., 2009). These processes may be expected to occur in many other long-living predatory species.

Decrease of food availability is caused by both smaller abundance of prey, lower diversity of species (prey items are needed throughout the season) and a reduced availability. Moreover, changes in microclimate may cause a shift towards smaller prey sizes, as has been reported for birds and bats by Siepel (1990), Beintema et al. (1991) and Schekkerman and Beintema (2007). The ratio behind this phenomenon is the longer development time for larger insects in general; when development rates are increased due to lower temperature sums in soil (Section 3.2), smaller species having faster development times may have a competitive advantage, resulting in smaller prey for insectivores. Smaller prey items and decreased diversity of prey, probably as a result from enhanced encroachment of coarse grasses and shrubs in open vegetation due to $\mathrm{N}$ deposition, resulted in lower reproductive rates of Redbacked Shrikes (Lanius collurio) in coastal dunes, leading to disappearance of the population (Kuper et al., 2000).

\section{Interaction between pathways and global environmental changes}

Increased nitrogen can cause effects on fauna through different parallel pathways that can strengthen or weaken the net effect for single animal species. This complex reaction is shown in detail for Threespine sticklebacks (Gasterosteus aculeatus) under increased growth of algae and phytoplankton due to nitrogen input by deposition and pollution in the Baltic Sea. Although a decrease in prey availability is expected due to reduced visibility, this mechanism reduced also aggressive interactions between males during the parental phase, resulting in higher density of breeding males in habitats with a denser growth of algae (Candolin, 2004) and enhancing reproductive output. Moreover, deterioration of condition of males slowed down and increased the reproductive lifespan of the males, enabling them to complete more breeding cycles (Candolin et al., 2008).

Another important factor, receiving more and more attention in the literature, is the interaction of increased $\mathrm{N}$ deposition with other global environmental changes, like climatic warming, rising $\mathrm{CO}_{2}$ levels, acidification of soil and water by $\mathrm{SO}_{\mathrm{x}}$ and an increase of invasive plant species. Porter et al. (2013) reports additive, synergistic as well as compensatory or antagonistic effects of $\mathrm{N}$ deposition, global warming and rising $\mathrm{CO}_{2}$ levels at an ecosystem level. Regarding plant chemical composition positive as well as negative interference occur between $\mathrm{N}$ deposition, raised $\mathrm{CO}_{2}$-levels and temperature changes caused by climate change (Hoover et al., 2012), but it is sure that foliar $\mathrm{P}$, and to a lesser extend foliar $\mathrm{N}$, vary in association with temperature and precipitation (Elser et al., 2010). Increased anthropogenic $\mathrm{N}$-deposition can enhance plant $\mathrm{N}$ as well as $\mathrm{P}$ concentrations in a $\mathrm{CO}_{2}$-enriched atmosphere (Huang et al., 2015) and Goverde and Erhardt (2003) already showed a change in food-plant preference for the butterfly Coenonympha pamphilus due to changes in host plant quality under increased $\mathrm{CO}_{2}$ levels. One of the 
most counterintuitive interactive effects concerns the aggravated cooling of the microclimate by global warming, because of lower temperature thresholds for growth in plants than in caterpillars, resulting in a higher vegetation and reduction of solar radiation to the soil (Wallis de Vries and Van Swaay, 2006). In several studies (a.o. Rao and Allen, 2010; Ochoa-Hueso et al., 2011) facilitation of invasive species due to increased $\mathrm{N}$ deposition is described thereby creating another possible threat for fauna species.

\section{Conclusions and future research}

In this review we show ten basic pathways leading to six different bottlenecks by which increased $\mathrm{N}$ deposition can affect animal species. Almost all of these bottlenecks work indirectly through changes in biomass, composition or nutritional quality of the vegetation. Scientific evidence on changes in vegetation due to increased $\mathrm{N}$ deposition, as well as for direct effects by chemical stress is abundant. However, for subsequent indirect effects on fauna evidence is still insufficient. This can be accounted for by the huge amount of ecological interactions underlying our simplified flow scheme, making it difficult to disentangle causal factors in practice, as well as to the diffuse character of the causal effects. These effects are rarely lethal in animal life stages visible for men and more often affect fecundity or reproductive success, or increase mortality in more cryptic life stages, thereby decreasing animal populations or alter competition between species in an almost invisible way. Also feedback mechanisms, like reduced performance of food plants due to increased herbivory with rising foliar nitrogen levels (Throop and Lerdau, 2004) complicate the clarifying of mechanisms, but are not included in the scheme for synoptic reasons.

With limited understanding of the causal factors, nature management cannot be optimised in relation to animal species and their habitats, including the risk of creating more severe problems for the target species than the ones that are solved. An example is given by Vogels et al. (2016) with sod-cutting leading to a reduction of grass encroachment in heathlands, but also affecting stoichiometry of plants with a detrimental effect on herbivore fauna. In order to adapt restoration measures to the real causes of decline for animal species we need a thorough understanding of the mechanisms launched by $\mathrm{N}$ deposition as described in this review. Ongoing global changes and the huge amount of environmental and ecological interactions that play a role in the net effect of $\mathrm{N}$ deposition make it even more important to study the different pathways affecting fauna.

This review can be used to focus future research on this topic. Although all identified pathways and bottlenecks are supported by peer reviewed literature, we conclude that scientific evidence on the causal relationship between increased $\mathrm{N}$ deposition and effects on fauna is still insufficient. Recently tested conceptual models (Meunier et al., 2016; Pöyry et al., 2016) and a meta-analysis by Simkin et al. (2016) provide initial assessment of the complex ecological changes due to increased $\mathrm{N}$ deposition, but do not give the detailed information on causal effects, which is necessary to develop counteracting or mitigating measures in practice. Controlled lab or greenhouse and field experiments in which a single pathway is studied or multiple pathways can be disentangled - such as Farrer and Suding (2016) for plant responses on $\mathrm{N}$ deposition - can provide the required knowledge, even more when dose-effect relations are included. The most severe gaps in knowledge concern subtle changes in plant chemistry and changes in availability of prey and host species to higher trophic levels of the food web.

Supplementary data to this article can be found online at http://dx. doi.org/10.1016/j.biocon.2017.02.022.

\section{Acknowledgements}

This review is based on a concise edition (in Dutch) commissioned by the Dutch Ministry of Economic Affairs. The authors would like to thank Dr. Rob Leuven (Radboud University Nijmegen), Dr. Toos van
Noordwijk (Wiltshire Wildlife Trust), Dr. Arnold van den Burg (Biosphere Science Productions), Dick Bal (Ministery of Economic Affairs), Dr. Nina Smits (Wageningen University) and Jaap Bouwman (Unie van Bosgroepen) for giving constructive remarks on earlier drafts of this paper.

\section{References}

Abbas, M., Klein, A.M., Ebeling, A., Oelmann, Y., Ptacnik, R., Weisser, W.W., Hillebrand, H., 2014. Plant diversity effects on pollinating and herbivorous insects can be linked to plant stoichiometry. J. Basic Appl. Ecol. 15, 169-178.

Audusseau, H., Kolb, G., Janz, N., 2015. Plant fertilization interacts with life history: variation in stoichiometry and performance in nettle-feeding butterflies. PLoS One 10, e0124616.

Beintema, A.J., Baarspul, T., De Krijger, J.P., 1997. Calcium deficiency in Black Terns Chlidonias niger nesting on acid bogs. Ibis 139, 396-397.

Beintema, A.J., Thissen, J.B., Tensen, D., Visser, G.H., 1991. Feeding ecology of charadriiform chicks in agricultural grassland. Ardea 79, 31-44.

Berg, M.P., Verhoef, H.A., 1998. Ecological characteristics of a nitrogen-saturated coniferous forest in The Netherlands. Biol. Fertil. Soils 26, 258-267.

Biesmeijer, J.C., Roberts, S.P.M., Reemer, M., Ohlemüller, R., Edwards, M., Peeters, T., Schaffers, A.P., Potts, S.G., Kleukers, R., Thomas, C.D., Settele, J., Kunin, W.E., 2006. Parallel declines in pollinators and insect-pollinated plants in Britain and the Netherlands. Science 313, 351-354.

Bink, F.A., 1992. De ecologische atlas van de dagvlinders van Noordwest Europa. Schuyt and $\mathrm{Co}$, Amsterdam.

Bobbink, R., 1991. Effects of nutrient enrichment in Dutch chalk grassland. J. Appl. Ecol. $28,28-41$.

Bobbink, R. Hicks, K. Galloway, J., Spranger, T, Alkemade, R. Ashmore, M. Bustamante, M., Cinderby, S., Davidson, E., Dentener, F., Emmett, B., Erisman, J.W., Fenn, M., Gilliam, F., Nordin, A., Pardo, L., De Vries, W., 2010. Global assessment of nitrogen deposition effects on terrestrial plant diversity: a synthesis. Ecol. Appl. 20, 30-59.

Camargo, J.A., Alonso, A., 2006. Ecological and toxicological effects of inorganic nitrogen pollution in aquatic ecosystems: a global assessment. Environ. Int. 32, 831-849.

Camargo, J.A., Alonso, A., Salamanca, A., 2006. Nitrate toxicity to aquatic animals: a review with new data for freshwater invertebrates. Chemosphere 58, 1258-1267.

Candolin, U., 2004. Effects of algae cover on egg acquisition in male three-spined stickleback. Behaviour 141, 1389-1399.

Candolin, U., Engström-Öst, J., Salesto, T., 2008. Human-induced eutrophication enhances reproductive success through effects on parenting ability in sticklebacks. Oikos 117 , 459-465.

Clark, C.M., Tilman, D., 2008. Loss of plant species after chronic low-level N deposition to prairie grassland. Nature 451, 712-715.

Cleland, E.E., Harpole, W.S., 2010. Nitrogen enrichment and plant communities. Ann. N. Y. Acad. Sci. 1195, 46-61.

De Sassi, C., Tylianakis, J.M., 2012. Climate change disproportionately increases herbivore over plant or parasitoid biomass. PLoS One 7, e40557.

Dennis, R.L.H., Shreeve, T.G., Van Dyck, H., 2003. Towards a functional resource-based concept for habitat: a butterfly biology viewpoint. Oikos 102, 417-426.

Elser, J.J., Peace, A.L., Kyle, M., Wojewodzic, M., McCrackin, M.L., Andersen, T., Hessen, D.O., 2010. Atmospheric N deposition is associated with elevated phosphorus limitation of lake zooplankton. Ecol. Lett. 13, 1256-1261.

Farrer, E.C., Suding, K.N., 2016. Teasing apart plant community responses to N enrichment: the roles of resource limitation, competition and soil microbes. Ecol. Lett. 19, 1287-1296.

Fartmann, T, Krämer, B, Stelzner, F, Poniatowski, D, 2012. Orthoptera as ecological indicators for succession in steppe grassland. Ecol. Indic. 20, 337-344.

Fedorenkova, A., Vonk, J.A., Lenders, H.J., Creemers, R., Breure, A.M., Hendriks, A.J., 2012. Ranking ecological risks of multiple chemical stressors on amphibians. Environ. Toxicol. Chem. 31, 1416-1421.

Fisher, K., Fiedler, K., 2000. Response of the copper butterfly Lycaena tityrus to increased leaf nitrogen in natural foods: evidence against the nitrogen limitation hypothesis. Oecologia 124, 235-241.

Fowles, A.P., Smith, R.G., 2006. Mapping the habitat quality of patch networks for the marsh fritillary Euphydryas aurinia (Rottemburg, 1775) (Lepidoptera, Nymphalidae) in Wales. J. Insect Conserv. 10, 161-177.

Fründ, J., Linsenmair, K.E., Blüthgen, N., 2010. Pollinator diversity and specialization in relation to flower diversity. Oikos 119, 1581-1590

Galloway, J.N., Townsend, A.R., Erisman, J.W., Bekunda, M., Cai, Z., Freney, J., Martinelli, L.A., Seitzinger, S.P., Sutton, M.A., 2008. Transformation of the nitrogen cycle: recent trends, questions, and potential solutions. Science 320 (5878), 889-892.

Geelen, J.F.M., Leuven, R.S.E.W., 1986. Impact of acidification on phytoplankton and zooplankton communities. Experientia 42, 486-494.

Gerhardt, A., 1993. Review of impact of heavy metals on stream invertebrates with special emphasis on acid conditions. Water Air Soil Pollut. 66, 289-314.

Goulson, D., Hughes, W., Derwent, L., Stout, J., 2002. Colony growth of the bumblebee, Bombus terrestris, in improved and conventional agricultural and suburban habitats. Oecologia 130, 267-273.

Goverde, M., Erhardt, A., 2003. Effects of elevated $\mathrm{CO}_{2}$ on development and larval foodplant preference in the butterfly Coenonympha pamphilus (Lepidoptera, Satyridae). Global Change Biology 9, 74-83.

Goverde, M., van der Heijden, M.V.D.H., Wiemken, A., Sanders, I., Erhardt, A., 2000. Arbuscular mycorrhizal fungi influence life history traits of a lepidopteran herbivore. Oecologia 125, 362-369. 
Graveland, J., Van der Wal, R., Van Balen, H., Van Noordwijk, A.J., 1994. Poor reproduction in forest passerines from decline of snail abundance on acidified soils. Nature 368 $446-448$.

Güsewell, S., 2004. N:P ratios in terrestrial plants: variation and functional significance. New Phytol. 164, 243-266.

Haddad, N.M., Haarstad, J., Tilman, D., 2000. The effects of long-term nitrogen loading on grassland insect communities. Oecologia 124, 73-84.

Hoover, S.E.R., Ladley, J.J., Shchepetkina, A.A., Tisch, M., Gieseg, S.P., Tylianakis, J.M., 2012. Warming, $\mathrm{CO}_{2}$, and $\mathrm{N}$ deposition interactively affect a plant-pollinator mutualism. Ecol. Lett. 15, 227-234.

Huang, W., Houlton, B.Z., Marklein, A.R., Liu, J., Zhou, G., 2015. Plant stoichiometric responses to elevated $\mathrm{CO} 2$ vary with nitrogen and phosphorus inputs: Evidence from a global-scale meta-analysis. Scientific reports 5.

Jones, M.E., Paine, T.D., Fenn, M.E., 2008. The effect of nitrogen additions on oak foliage and herbivore communities at sites with high and low atmospheric pollution. Environ. Pollut. 151, 434-442.

Jones, M.E., Fenn, M.E., Paine, T.D., 2011. The effect of nitrogen additions on bracken fern and its insect herbivores at sites with high and low atmospheric pollution. Arthropod Plant Interact. 5, 163-173.

Kanakidou, M., Myriokefalitakis, S., Daskalakis, N., Fanourgakis, G., Nenes, A., Baker, A.R., Tsigaridis, K., Mihalopoulos, N., 2016. Past, present, and future atmospheric nitrogen deposition. J. Atmos. Sci. 73, 2039-2047.

Kleijn, D., Raemakers, I., 2008. A retrospective analysis of pollen host plant use by stable and declining bumble bee species. Ecology 89, 1811-1823.

Klop, E., Omon, B., WallisDeVries, M.F., 2015. Impact of nitrogen deposition on larval habitats: the case of the wall brown butterfly Lasiommata megera. J. Insect Conserv. 19, 393-402.

Konvicka, M., Hula, V., Fric, Z., 2003. Habitat of pre-hibernating larvae of the endangered butterfly Euphydryas aurinia (Lepidoptera: Nymphalidae): What can be learned from vegetation composition and architecture? Eur. J. Entomol. 100, 313-322.

Kuper, J., Van Duinen, G.J., Nijssen, M., Geertsma, M., Esselink, H., 2000. Is the decline of the red-backed shrike (Lanius collurio) in the Dutch coastal dune area caused by a decrease in insect diversity? Ring 22, 11-25.

Lensink, B.M., 1963. Distribution ecology of some Acrididae (Orthoptera) in the dunes of Voorne, Netherlands - Tijdschr. Entomologo 106, 357-443.

Leuven, R.S.E.W., Oyen, F.G.F., 1987. Impact of acidification and eutrophication on the distribution of fish species in shallow and lentic soft waters of The Netherlands: an historical perspective. J. Fish Biol. 31, 753-774.

Leuven, R.S.E.W., Den Hartog, C., Christiaans, M.M.C., Heijligers, W.H.C., 1986a. Effects of water acidification on the distribution pattern and the reproductive success of amphibians. Experientia 42, 495-503.

Leuven, R.S.E.W., Kersten, H.L.M., Schuurkes, J.A.A.R., Roelofs, J.G.M., Arts, G.H.P., 1986b. Evidence for recent acidification of lentic soft waters in The Netherlands. Water Air Soil Pollut. 30, 387-392.

Liu, X., Duan, L., Mo, J., Du, E., Shen, J., Lu, X., Zhang, Y., Zhou, X.B., He, C.N., Zhang, F., 2011. Nitrogen deposition and its ecological impact in China: an overview. Environ. Pollut. 159, 2251-2264.

Meunier, C.L., Gundale, M.J., Sánchez, I.S., Liess, A., 2016. Impact of nitrogen deposition on forest and lake food webs in nitrogen-limited environments. Glob. Chang. Biol. 22, 164-179.

Mogren, C.L., Trumble, J.T., 2010. The impacts of metals and metalloids on insect behavior. Entomol. Exp. Appl. 135, 1-17.

Mohan, J.E., Cowden, C.C., Baas, P., Dawadi, A., Frankson, P.T., Helmick, K., Taylor, M., 2014. Mycorrhizal fungi mediation of terrestrial ecosystem responses to global change: mini-review. Fungal Ecol. 10, 3-19.

Mulder, C., 2010. Soil fertility controls the size-specific distribution of eukaryotes. Ann. N. Y. Acad. Sci. 1195, 74-81.

Nijssen, M., Siepel, H., 2010. The characteristic fauna of drift sands. In: Fanta, J., Siepel, H. (Eds.), Inland Drift sand Landscapes. KNNV-Uitgeverij, Driebergen, pp. 255-278.

Ochoa-Hueso, R., Allen, E.B., Branquinho, C., Cruz, C., Dias, T., Fenn, M.E., Stock, W.D., 2011 Nitrogen deposition effects on Mediterranean-type ecosystems: an ecological assessment. Environ. Pollut. 159, 2265-2279.

Öckinger, E., Hammarstedt, O., Nilsson S.G., Smith, H.G., 2006. The relationship between local extinctions of grassland butterflies and increased soil nitrogen levels. Biol. Conserv. 128, 564-573.

Økland, J., 1992. Effects of acidic water on freshwater snails: results from a study of 1000 lakes throughout Norway. Environ. Pollut. 78, 127-130.

Ormerod, S.J., Rundle, S.D., 1998. Effects of experimental acidification and liming on terrestrial invertebrates: implications for calcium availability to vertebrates. Environ. Pollut. 103, 183-191.

Ormerod, S.J., O'Halloran, J., Gribbin, S.D., Tyler, S.J., 1991. The ecology of dippers Cinclus cinclus in relation to stream acidity in upland Wales: breeding performance, calcium physiology and nestling growth. J. Appl. Ecol. 28, 419-433.

Pabian, S.E., Brittingham, M.C., 2007. Terrestrial liming benefits birds in an acidified forest in the Northeast. Ecol. Appl. 17, 2184-2194.

Pabian, S.E., Rummel, S.M., Sharpe, W.E., Brittingham, M.C., 2012. Terrestrial liming as a restoration technique for acidified forest ecosystems. Intern. J. Forest. Res. 2012

Peeters, T.M.J., Van Achterberg, C., Heitmans, W.R.B., Klein, W.F., Lefeber, V., Van Loon, A.J., Mabelis, A.A., Nieuwenhuijsen, H., Reemer, M., De Rond, J., Smit, J., Velthuis, H.H.W., 2004. De wespen en mieren van Nederland (Hymenoptera: Aculeata). - Nederlandse Fauna 6, NNM Naturalis Leiden, KNNV Uitgeverij Utrecht and EIS-Nederland Leiden (in Dutch).

Persson, J., Fink, P., Goto, A., Hood, J.M., Jonas, J., Kato, S., 2010. To be or not to be what you eat: regulation of stoichiometric homeostasis among autotrophs and heterotrophs. Oikos 119, 741-751.
Porter, E.M., Bowman, W.D., Clark, C.M., Compton, J.E., Pardo, L.H., Soong, J.L., 2013. Interactive effects of anthropogenic nitrogen enrichment and climate change on terrestrial and aquatic biodiversity. Biogeochemistry 114, 93-120.

Pöyry, J., Carvalheiro, L.G., Heikkinen, R.K., Kühn, I., Kuussaari, M., Schweiger, O., Valtonen, A., van Bodegom, P.M., Franzén, M., 2016. The effects of soil eutrophication propagate to higher trophic levels. Glob. Ecol. Biogeogr. http://dx.doi.org/10.1111/geb.12521.

Rainbow, P.S., 2002. Trace metal concentrations in aquatic invertebrates: why and so what? Environ. Pollut. 120, 497-507.

Rao, L.E., Allen, E.B., 2010. Combined effects of precipitation and nitrogen deposition on native and invasive winter annual production in California deserts. Oecologia 162 , 1035-1046.

Remke, E., Brouwer, E., Kooijman, A., Blindow, I., Esselink, H., Roelofs, J.G., 2009. Even low to medium nitrogen deposition impacts vegetation of dry, coastal dunes around the Baltic Sea. Environ. Pollut. 157, 792-800.

Roem, W.J., Berendse, F., 2000. Soil acidity and nutrient supply ratio as possible factors determining changes in plant species diversity in grassland and heathland communities. Biol. Conserv. 92, 151-161.

Roy, D.B., Thomas, J.A., 2003. Seasonal variation in the niche, habitat availability and population fluctuations of a bivoltine thermophilous insect near its margin. Oecologia $134,439-444$.

Salz, A., Fartmann, T., 2009. Coastal dunes as important strongholds for the survival of the rare Niobe fritillary (Argynnis niobe). J. Insect Conserv. 13, 643-654.

Sardans, J., Rivas-Ubach, A., Peñuelas, J., 2012. The C: N: P stoichiometry of organisms and ecosystems in a changing world: a review and perspectives. Persp. Plant Ecol. Evol. Syst. 14, 33-47.

Sauliutė, G., Svecevičius, G., 2015. Heavy metal interactions during accumulation via direct route in fish: a review. Zool. Ecol. 25, 77-86.

Schekkerman, H., Beintema, A.J., 2007. Abundance of invertebrates and foraging success of black-tailed godwit Limosa limosa chicks in relation to agricultural grassland management. Ardea 95, 39-54.

Schekkerman, H., Boele, A., 2009. Foraging in precocial chicks of the black-tailed godwit Limosa limosa: vulnerability to weather and prey size. J. Avian Biol. 40, 369-379.

Scheper, J., Reemer, M., Van Kats, R., Ozinga, W.A., Van der Linden, G.T.J., Schaminée, J.H.J., Siepel, H., Kleijn, D., 2014. Museum specimens reveal loss of pollen host plants as key factor driving wild bee decline in the Netherlands. Proc. Nat. Acad. Soc. 111 $17552-17557$.

Schirmel, J., Fartmann, T., 2014. Coastal heathland succession influences butterfly community composition and threatens endangered species. J. Insect Conserv. 18 $111-120$.

Schirmel, J., Mantilla-Contreras, J., Blindow, I., Fartmann, T., 2011. Impacts of succession and grass encroachment on heathland Orthoptera. J. Insect Conserv. 15, 633-642.

Shreeve, T.G., 1990. Microhabitat use and hindwing phenotype in Hipparchia semele (Lepidoptera, Satyrinae): thermoregulation and background matching. J. Econ. Entomol. $15,201-213$.

Siepel, H., 1990. The influence of management on food size in the menu of insectivorous animals. In: Sommeijer, M.J., van der Blom, J. (Eds.), Experimental and Applied Entomology. Proc. Neth. Entomol. Soc. Amsterdam I, pp. 69-74.

Siepel, H., Verstrael, Th.J., Van den Burg, A.B., Vogels, J.J., 2009. Herstel van lange termijn effecten van verzuring en vermesting in het droog zandlandschap. De Levende Natuur. 110 pp. 124-129 (in Dutch with English abstract).

Simkin, S.M., Allen, E.B., Bowman, W.D., Clark, C.M., Belnap, J., Brooks, M.L., Cade, B.S. Collins, S.L., Geiser, L.H., Gilliam, F.S., Jovan, S.E., Pardo, L.H., Schulz, B.K., Stevens, C.J., Suding, K.N., Throop, H.L., Waller, D.M., 2016. Conditional vulnerability of plant diversity to atmospheric nitrogen deposition across the United States. Proc. Natl. Acad. Sci. 113, 4086-4091.

Skeffington, R.A., Wilson, E.J., 1988. Excess N deposition: issues for consideration. Environ. Pollut. 54, 159-184.

Sowig, P., 1989. Effects of flowering plant's patch size on species composition of pollinator communities, foraging strategies, and resource partitioning in bumblebees (Hymenoptera: Apidae). Oecologia 78, 550-558.

Stevens, C.J., Dise, N.B., Mountford, J.O., Gowing, D.J., 2004. Impact of N deposition on the species richness of grasslands. Science 303, 1876-1879.

Stevens, C.J., Duprè, C., Dorland, E., Gaudnik, C., Gowing, D.J.G., Bleeker, A., Diekmann, M., Alard, D., Bobbink, R., Fowler, D., Corcket, E., Mountford, J.O., Vandvik, V., Aarrestad, P.A., Muller, S., Dise, N.B.E., 2011. The impact of nitrogen deposition on acid grasslands in the Atlantic region of Europe. Environ. Pollut. 159, 2243-2250.

Stoutjesdijk, P., Barkman, J.J., 2014. Microclimate, Vegetation and Fauna. 2nd extended edition. KNNV Publishing, Zeist.

Streitberger, M., Rose, S., Hermann, G., Fartmann, T., 2014. The role of a mound-building ecosystem engineer for a grassland butterfly. J. Insect Conserv. 18, 745-751.

Sutton, M.A., Mason, K.E., Sheppard, L.J., Sverdrup, H., Haeuber, R., Hicks, W.K., 2014. Nitrogen Deposition Critical Loads and Biodiversity. Dordrecht. Springer (535 pp).

Tao, L., Hunter, M.D., 2012. Does anthropogenic nitrogen deposition induce phosphorus limitation in herbivorous insects? Glob. Chang. Biol. 18, 1843-1853.

Tao, L.L., Berns, A.R., Hunter, M.D., 2014. Why does a good thing become too much? Interactions between foliar nutrients and toxins determine performance of an insect herbivore. Funct. Ecol. 28, 190-196.

Throop, H.L., 2005. N deposition and herbivory affect biomass production and allocation in an annual plant. Oikos $111,91-100$

Throop, H.L., Lerdau, M.T., 2004. Effects of N deposition on insect herbivory: implications for community and ecosystem processes. Ecosystems 7, 109-133.

Tyler, S.J., Ormerod, S.J., 1992. A review of the likely causal pathways relating the reduced density of breeding dippers Cinclus cinclus to the acidification of upland streams. Environ. Pollut. 78, 49-55.

Van Noordwijk, C.G.E., Boer, P., Mabelis, A.A., Verberk, W.C.E.P., Siepel, H., 2012. Life-history tactic analysis reveals fragmentation and low soil temperature due to inadequate 
management to be main bottlenecks for ant communities in Dutch chalk grasslands. Ecol. Indic. 13, 303-313.

Van Turnhout, C.A.M., Leuven, R.S.E.W., Hendriks, A.J., Kurstjens, G., Van Strien, A.J. Foppen, R.P.B., Siepel, H., 2012. Ecological strategies successfully predict the effects of river floodplain rehabilitation on breeding birds. River Res. Appl. 28, 269-282.

Van Wingerden, W.K.R.E., Musters, J.C.M., Maaskamp, F.I.M., 1991. The influence of temperature on the duration of egg development in West European grasshoppers (Orthoptera: Acrididae). Oecologia 87, 417-432.

Van Wingerden, W.K.R.E., Van Kreveld, A.R., Bongers, W., 1992. Analysis of species composition and abundance of grasshoppers (Orth. Acrididae) in natural and fertilized grasslands. J. Appl. Entomol. 113, 138-152.

Visser, M.E., 2008. Keeping up with a warming world; assessing the rate of adaptation to climate change. Proc. R. Soc. B 275, 649-659.

Vitousek, P.M., Aber, J.D., Howarth, R.W., Likens, G.E., Matson, P.A., Schindler, D.W., Schlesinger, W.H., Tilman, D.G., 1997. Human alteration of the global nitrogen cycle: sources and consequences. Ecol. Appl. 7, 737-750.

Vogels, J.J., Verberk, W.C.E.P., Lamers, L.P.M., Siepel, H., 2016. Stoichiometrical imbalances in plant chemistry drive the decline of invertebrate heathland fauna following nitrogen deposition and soil acidification. Biol. Conserv. (this volume).
Wallis de Vries, M.F., Van Swaay, C.A.M., 2006. Global warming and excess nitrogen may induce butterfly decline by microclimatic cooling. Glob. Chang. Biol. 12, 160-1626.

WallisDeVries, M.F., 2004. A quantitative conservation approach for the endangered butterfly Maculinea alcon. Conserv. Biol. 18, 489-499.

WallisDeVries, M.F., Van Swaay, C.A.M., Plate, C.L., 2012. Changes in nectar supply: a possible cause of widespread butterfly decline. Curr. Zool. 58, 384-391.

Weiss, S.B., 1999. Cars, cows, and checkerspot butterflies: N deposition and management of nutrient-poor grasslands for a threatened species. Conserv. Biol. 13, 1467-1486.

Westphal, C., Steffan-Dewenter, I., Tscharntke, T., 2006. Bumblebees experience landscapes at different spatial scales: possible implications for coexistence. Oecologia 149, 289-300.

Willmer, P.G., 1982. Microclimate and the environmental physiology of insects. Adv. Insect Physiol. 16, 1-57.

Wünsch, Y., Schirmel, J., Fartmann, T., 2012. Conservation management of coastal dunes for Orthoptera has to consider oviposition and nymphal preferences. J. Insect Conserv. 16, 501-510.

Xu, J., Wang, Y., Luo, Y.M., Song, J., Ke, X., 2009. Effects of copper, lead and zinc in soil on egg development and hatching of Folsomia candida. J. Insect Sci. 16, 51-55. 